\title{
Geomorphological maps as the basis of hazard mapping in Japan
}

\author{
Yohta KUMAKI $^{\mathrm{a}}{ }^{*}$, Sumiko KUBO ${ }^{\mathrm{b}}$ \\ ${ }^{a}$ Senshu University, kumaki@isc.senshu-u.ac.jp \\ ${ }^{b}$ Waseda University, sumik@waseda.jp \\ * Corresponding author
}

Keywords: Geomorphological map, Hazard map, Landform

\begin{abstract}
:
Japanese Islands are situated along the tectonically very active zone. Earthquakes occur frequently, and there are many active volcanoes. Climatically Japan is located in the east Asian monsoon zone and has high annual precipitation. Tropical cyclones (typhoons) or baiu (early summer rain season) sometimes lead to torrential rainfall. Such natural conditions have created broad high mountain areas and rivers of strong erosional process. Mountain slopes are geologically open to collapse, and debris flows often occur in streams in mountainous areas. While the area of alluvial plains, underlain by thick unconsolidated sediment, account for only $25 \%$ of the whole of Japan, approximately $80 \%$ of the population is concentrated in these weak-ground areas. Owing to such geographical characteristics, people have suffered many and various natural disasters (earthquake ground motion, liquefaction, landslide, debris flow, river flood, high tide, tsunami, etc.) in Japan.
\end{abstract}

In 1959, a very strong typhoon (Isewan Typhoon or Typhoon Vera) brought the greatest flood damage in Nagoya City and its surrounding area. More than 5,000 people were killed or missing by it. The major damage was caused by high tide inundation in the delta of the Nobi plain. Three years before the disaster, Masahiko OYA (1923-2005) made a 1:50,000 geomorphological map of the plain. The damaged area had been shown in the map which was based on geomorphic features. After this, it became well-known that geomorphological mapping is effective for understanding flood risks.

Since then, the various natural disasters have been studied by Japanese geomorphologists and the relationship between the damage and geomorphological condition has been revealed. Nowadays we know that the geomorphological land condition influences very much not only the damage by earthquake strong motion but also occurrence of ground liquefaction. It is also well-known that landforms derived by landslide or debris flow shown in a geomorphological map mean that the place is open to damage in the future.

The national government carried out and is carrying out some geomorphological mapping projects for the purpose of hazard assessments. Nowadays, national and local governments prepare various kinds of "hazard map" which show probably dangerous zones, and some of them are made using the information provided from geomorphological maps.

Major geomorphological mapping projects are as follows:

Chikei Burui $\mathrm{Zu}$ (Landform Classification Map) 1:50,000 , 1953-

This project intended not to use for hazard assessment but to contribute to the development conservation and higher utilization of land in the rapid population growth period. At first, this project executed by the Geographical Survey Institute (national survey and mapping agency of Japan, present name: Geospatial Information Authority of Japan, GSI), but most of maps has been prepared by prefectural governments. Most part of Japan has been covered. We can see the maps on a website of the Ministry of Land, Infrastructure and Transport and on the web-GIS (Chiriin Chizu) of GSI.

http://nrb-www.mlit.go.jp/kokjo/inspect/landclassification/land/1_national_map_5-1.html

Suigai Chikei Bunrui Zu (Geomorphological Survey Map of River Basins Showing Classification of Flood Stricken Areas) 1956-2001

35 maps of this series, the scale of which are mainly 1;50,000 or 1:25,000, were made by OYA and his co-workers. The above-mentioned geomorphological map of the Nobi plain is the first one. The mapping was made from a viewpoint that the micro-landforms of a plain reflect the history of flooding because they have been formed by the deposition process during the flood time, and therefore they enable us to estimating flooding in the future. The project was sponsored by some government organizations, especially river offices. Oya and his co-workers also made 10 maps in foreign countries of Asia and Africa. Today, we can see the maps on the website of the National Research Institute for Earth Science and Disaster Resilience (NIED) . 
http://ecom-plat.jp/suigai-chikei/index.php?gid=10006

Tochi Joken Zu (Land Condition Map) 1:25,000, 1963-2013

This project executed systematically by the GSI. The mapping concept is similar to the Suigai Chikei Bunrui Zu for plain area. In addition, it is characteristic that the slope type is shown in mountainous area. Cover area is most part of large plain area. Paper sheet maps are prepared in the surveyed area finished before 2007. The survey results after 2008 (mainly revision) are provided as digital data. Today, we can see the maps on a website of the Ministry of Land, Infrastructure and Transport and on the web-GIS of GSI.

\section{Chisui Chikei Bunrui Zu (Geomorphological map for prediction of flooding) 1:25,000, 1976-78, 2007-(revision)}

This project executed systematically by the GSI. Cover area is plains in big river basins, the rivers of which are managed by the national government. The mapping concept of this map series is similar to the Suigai Chikei Bunrui Zu and Tochi Joken $\mathrm{Zu}$, but landform classification is simpler for the use of river engineers who are not geomorphologists. Today, we can see the maps on the web-GIS of GSI.

Jisuberi Chikei Bunpu Zu (Landslide Distribution Map) mainly 1:50,000 (partially 1:25,000), 1982-

This map series has prepared as a result of large landslide studies of NIED. We can see the maps on the website of NIED.

http://www.j-shis.bosai.go.jp/map/?lang=en

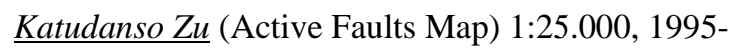

This map series has prepared as a result of detailed studies by the geomorphologists belonging universities and some research institutes organized by GSI. Characteristics of active faults shown of this map series are used as important data for the long-term evaluation of earthquake occurrence possibility by the national committee of the authority. Paper sheet maps are published as well as the image is visible on the web-GIS of GSI.

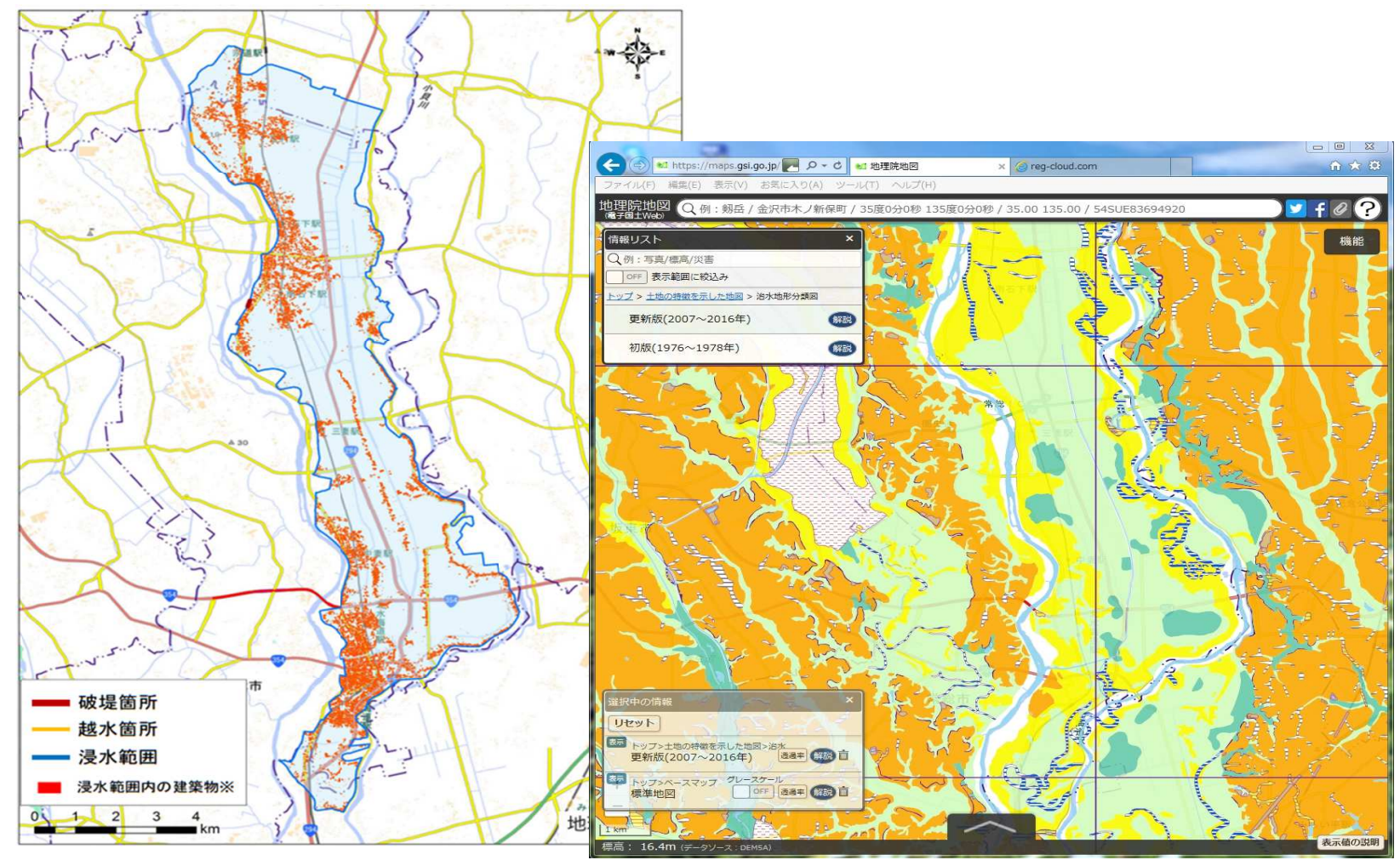

Figure 1. Inundation area in 2015 (left), Chisui Chikei Bunrui $\mathrm{Zu}$ on the web (right) Siource: GIS website

Left blue: inundation area

Right green: wetland, light green: lowland, yellow: natural levee, sand dune, etc., orange: upland 